\title{
Highs and lows: the effect of differently sized freshwater inflows on estuarine carbon, nitrogen, phosphorus, bacteria and chlorophyll $a$ dynamics
}

James N. Hitchcock ${ }^{a, c}$ and Simon M. Mitrovic ${ }^{a, b}$

${ }^{a}$ Centre for Environmental Sustainability, School of the Environment, University of Technology, Sydney, PO Box 123, Broadway, NSW 2007, Australia

${ }^{\mathrm{b}}$ New South Wales Office of Water, Water, Elizabeth Macarthur Agricultural Institute, Private Bag 4008 Narellan 2567 NSW, Australia.

${ }^{\mathrm{C}}$ Corresponding author. Email: james.hitchcock@uts.edu.au

Keywords: organic carbon, estuary, river, flow, discharge, bacteria

\begin{abstract}
Freshwater inflows play a key role in the delivery of organic carbon to estuaries. However, our understanding of the dynamics between discharge and carbon globally is limited. In this study we performed a 30-month monitoring study on the Bega and Clyde River estuaries, Australia, to understand the influence that discharge had on carbon, nitrogen, phosphorus, bacteria and chlorophyll $a$ dynamics. We hypothesised that 1) discharge would be the most important factor influencing carbon and nutrient concentrations, though during low flows chlorophyll $a$ would also be positively related to carbon, 2) bacteria would be related to dissolved organic carbon (DOC), and chlorophyll $a$ to temperature, nitrogen and phosphorus, and 3) that concentrations of carbon, nitrogen, phosphorus, bacterial biomass and chlorophyll $a$ would be significantly different between large 'flood flows', smaller 'fresh flows' and base flow conditions. We found that discharge was always the most important factor influencing carbon and nutrient concentrations, and that primary production appeared to have little influence on the variation in DOC concentration even during base flow conditions. We suggest this relationship is likely due to highly episodic discharge that occurred during the
\end{abstract}


study period. Bacteria were related to DOC in the lower estuary sites, but phosphorus in the upper estuary. We suggest this is likely due to the input of bioavailable carbon in the upper estuary leading bacteria to be $\mathrm{P}$ limited, which changes downstream to carbon limitation as DOC becomes more refractory. Chlorophyll $a$ was positively related to temperature but not nutrients, which we suggest may be due to competition with bacteria for phosphorus in the upper estuary. Carbon, nitrogen and phosphorus concentrations were different under flood, fresh and base flow conditions, though these differences sometimes varied between estuary locations for different resources. Overall, the results demonstrate that discharge plays an important structuring role for carbon, nutrient and bacteria dynamics on the Bega and Clyde Rivers, and that the differences observed between flood and fresh inflows suggest that further study into the influence of differently sized inflow events is important.

\section{Introduction}

Freshwater inflows play a critical role in defining estuarine functioning. Each year rivers transport, transform and store up to $1.9 \mathrm{pg} \mathrm{C}^{-1}$, of which around half is transported to estuaries and coasts (Cole et al., 2007). Biogeochemists have a long history of studying organic matter in aquatic ecosystems (Findlay, 2003). Despite this, as suggested by Cauwet (2002), having a precise understanding of the nature of organic carbon delivered by rivers is difficult. Part of this stems from the overwhelming complexity and dynamism of the processes involved. At the catchment scale, there are a variety of factors that influence carbon dynamics including; precipitation, land use, temperature, water regulation and dams, soil and vegetation types and geomorphology (Findlay and Sinsabaugh, 2003). When riverine carbon enters the estuary there are another set of influencing factors including; biological transformation, production of autochthonous carbon (primary production within the estuary), retention time, mixing and dilution, flocculation, adsorbtion and aggregation (Day et al., 
2012). Essentially this means that predicting the relationship between discharge and organic carbon in a particular system is extremely difficult without long-term data that captures both temporal and spatial variability.

The majority of allochthonous carbon enters rivers, and in turn estuaries, during episodic flow events (Hinton et al., 1997; Raymond and Saiers, 2010; Webster et al., 1987; Westhorpe and Mitrovic, 2012). A number of studies have conceptualised hydrologic conditions in the rivers as 'storm flow' and 'base flow' which has been useful in demonstrating that whilst storm flow conditions only occur for short periods of time, they disproportionally account for a large portion of organic carbon exported from the catchment (Buffam et al., 2001; Hinton et al., 1997; Raymond and Saiers, 2010). Puckridge et al. (1998), whilst not specifically talking about carbon dynamics, went further separating storm flow conditions into 'flood pulses' and 'flow pulses'. Flood pulses are large flows of water that inundate floodplains and may variably occur every year or two, whereas flow pulses are smaller flow events where water does not break the banks of a channel and occur more frequently. Few studies that have approached the topic of discharge and carbon in estuaries have utilised these types of frameworks to describe conditions. Such a framework may prove a useful way of discerning the different ways that discharge influences the movement of carbon in estuaries.

Phytoplankton and bacteria both play keys roles in the carbon, nitrogen and phosphorus cycles (Lin et al., 2006). A great deal of attention has been paid to the influence of autochthonous vs. allochthonous influences on estuarine metabolism (McDowell and Asbury, 1994). It is common that carbon is more related to discharge during wet or high flow periods and related to primary production during dry or low flow periods (Ochs et al., 2010). In many systems where allochthonous inputs are small, primary production is the main source of dissolved organic carbon and in turn bacterial production is closely coupled with phytoplankton biomass or chlorophyll $a$ (Cole et al., 1988). In estuaries, phytoplankton are 
predominantly limited by temperature and the availability of nitrogen and phosphorus (Eppley, 1972). Nutrient limitation may be relieved with freshwater inflows that bring available nitrogen and phosphorus, but conversely if inflows bring high loads of suspended sediment or coloured organic matter then primary production may be light limited (Cloern, 1987).

When allochthonous inputs are high, bacteria may become uncoupled from phytoplankton or chlorophyll $a$ (Hoch and Kirchman, 1993; Ning et al., 2005). Bacteria are most regularly limited by DOC (Malone, 1977) but may also be limited by nitrogen and phosphorus and may compete with phytoplankton for nutrients (Thingstad et al., 1998). Bacteria can quickly metabolise available DOC acting as a significant carbon sink, as well as a potential link for organic matter subsidising food webs (Findlay et al., 1992). Estuaries are commonly net heterotrophic, indicating the importance of allochthonous carbon to bacterial metabolism (Fouilland and Mostajir, 2010). Understanding how discharge affects these processes has far reaching ecological implications.

Much of our knowledge about estuarine carbon, nitrogen and phosphorus dynamics derives from North American and European systems (Tank et al., 2010 and references therein). The last decade has seen increasing studies occurring outside of these regions (for example Thottathil et al., 2008; Vargas et al., 2011). In Australia the study of organic carbon in estuaries has been fairly limited (Abrantes and Sheaves, 2010; Eyre and Twigg, 1997; Ford et al., 2005; Petrone, 2010; Petrone et al., 2011; Petrone et al., 2009). Thus, there is a need to pay greater attention to Australian catchments, in particular as temperate and sub-tropical systems in Australia exhibit particularly episodic discharge and precipitation (Finlayson and McMahon, 1988).

The purpose of our study was to investigate the influence that freshwater inflows have on organic carbon and nutrient dynamics and how these dynamics change between flood, fresh 
and base flow conditions. We hypothesised that 1) carbon, nitrogen and phosphorus concentrations can be explained through a combination of discharge, and for DOC, chlorophyll $a$ during base flows, 2) that bacteria are related to DOC concentrations and phytoplankton to temperature as well as nitrogen and phosphorus and 3) that carbon, nutrient and bacteria concentrations are highest during flood flows and chlorophyll $a$ concentrations highest during fresh flows. This work was carried out on the Bega and Clyde River estuaries, which were chosen as they are situated in a region of Australia where carbon dynamics have not previously been reported. Our study took place over a 30 month period, encompassing a range of monitoring stations spanning the length of each estuary. Sampling occurred on a monthly basis, with increased frequency during and after high flow events in order to capture the full range of flow variability.

\section{Materials and Methods}

\section{Study sites}

The Bega River estuary, NSW, Australia, (-36 42' 43.64", $\left.+149^{\circ} 54^{\prime} 8.76^{\prime \prime}\right)$ is a shallow, wave-dominated estuary (Fig. 2.1). The estuarine volume, 6371 ML, is relatively small compared to its catchment of $1941 \mathrm{~km}^{2}$ (Roy et al., 2001). The catchment is split into two sub-catchments, the Brogo River, regulated by Brogo Dam and Bega River which has two smaller dams, Cochrane and Candello. The upper sections of the catchment consist of mainly forested areas, whilst the middle catchment is mostly cleared for agriculture, dominated by the dairy industry (Brierley et al., 1999; Tozer et al., 2010). The freshwater tidal section has been mostly cleared for agriculture and irrigated farmland, however the rest of the estuary is largely unmodified. Broad scale land clearing since colonisation has drastically altered the river and estuary via the transportation of sandy top soils into the river channel (Brooks and 
Brierley, 1997). Mean annual rainfall is $605 \mathrm{~mm}$ (1994-2014) and was above average between 2010-2012 with a mean of $862 \mathrm{~mm}$ per year.

The Clyde River estuary, NSW, Australia, (-35³3' 11.44", $\left.+150^{\circ} 11^{\prime} 12.11^{\prime \prime}\right)$ is a tidally dominated estuary (Fig. 2.1). Its estuary volume, $50737 \mathrm{ML}$ is relatively large compared to its catchment size, $1791 \mathrm{~km}^{2}$ (Roy et al., 2001). The river is unregulated, with no significant structures or water extraction. The catchment is almost entirely forested, with some forestry activities in the upper catchment. The lower sections of the estuary have a small urban settlement as well as oyster and other fisheries activities (Tozer et al., 2010). Average rainfall is $889 \mathrm{~mm}$ (1991-2014) and was above average between 2010-2012 with a mean of 1027 $\mathrm{mm}$.

On each estuary five monitoring stations were sampled encompassing the length of the estuary (Fig. 2.1). Salinity ranged from 0 (at station 1) to 35 (at station 5) on the practical salinity scale.

\section{Discharge and Flow Classification}

Discharge information was obtained from one gauging station on the Clyde River and two gauging stations on the Bega and Brogo Rivers, which were combined to give a single value for the Bega River. Discharge $\left(\mathrm{m}^{3} \mathrm{~s}^{-1}\right)$ data presented here was calculated as a daily average flow rate. On the Bega River these gauging stations were located approximately $5 \mathrm{~km}$ upstream of the tidal zone and on the Clyde River the gauging station is located approximately $11 \mathrm{~km}$ upstream of the tidal zone. There are no tributaries located between the gauging stations and tidal zone. In order to distinguish base flow from storm flow conditions hydrograph separation was performed via WHAT system recursive digital filter method (Lim et al., 2005), with a filter parameter of 0.98 and $\mathrm{BFI}_{\max }$ of 0.80 . Sampling that occurred during storm flow conditions were further conceptualised as either flood flow $>150 \mathrm{~m}^{3} \mathrm{~s}^{-1}$ or fresh flow $<150 \mathrm{~m}^{3} \mathrm{~s}^{-1}$. This threshold was chosen as it differentiated the flood and fresh flows 
based on our observations of over the bank flooding in the freshwater tidal reaches of both rivers.

\section{Sampling procedures and analyses}

Sampling was performed between June 2010 and November 2012. On the Bega River sampling occurred on five occasions during flood flows, eight occasions during fresh flows and 26 occasions during base flow conditions. The Clyde River was sampled on seven occasions during flood flows, seven occasions during fresh flows and 23 occasions during base flow conditions (Fig. 2). Sampling was performed moving upstream on the ebb tide within 0-2 hours of high tide at the mouth of each estuary. Temperature, conductivity, dissolved oxygen and pH were measured with a Hydrolab Surveyor and MS5 Sonde probe. Turbidity samples were measured using a Hach 2100 turbidimeter.

Triplicate samples for dissolved organic carbon (DOC), particulate organic carbon (POC), total nitrogen (TN), total phosphorus (TP) and chlorophyll $a$ were taken by hand $20 \mathrm{~cm}$ below the water surface. DOC and POC samples were collected in pre-combusted and sample rinsed $100 \mathrm{~mL}$ glass bottles, acidified with $2 \mathrm{~N}$ hydrochloric acid and refrigerated at $4^{\circ} \mathrm{C}$. Samples were analysed in the laboratory by the High Temperature Combustion Method (APHA, 2005) with DOC samples being pre-filtered to $0.45 \mu \mathrm{m}$ using PTFE syringe filters. TN and TP samples were collected in pre-washed and sample rinsed $50 \mathrm{~mL}$ PET bottles, frozen and later analysed using a segmented flow analyzer (OI Analytical Model FS3100) according to standard methods (APHA, 2005).

Samples for chlorophyll $a$ were determined by filtering $500 \mathrm{~mL}$ of water onto GF/C filters. Filters were frozen until subsequent determination by Standard Methods (APHA, 2005) using the grinding technique and acetone as a solute with correction for phaeophytin. A detection limit of $1 \mu \mathrm{g} \mathrm{L}^{-1}$ was used for chlorophyll $a$ analysis. Bacterial biomass samples $(10 \mathrm{~mL})$ were collected in sterile centrifuge tubes and fixed with $0.4 \mathrm{~mL}$ of concentrated $0.2 \mu \mathrm{m}$ filtered 
formalin ( $37 \%$ Formaldehyde) and stored at $4{ }^{\circ} \mathrm{C}$. In the laboratory, subsamples $(2 \mathrm{~mL})$ were stained with DAPI (4'6-diamindion-2-phenylindole) at a final concentration of $1 \mathrm{mg} \mathrm{mL}^{-1}$ for 15 minutes, and filtered through a polycarbonate black $0.2 \mu \mathrm{m}$ pore-sized filter (Porter and Feig, 1980). Polycarbonate filters were mounted onto microscope slides and non-fluorescence immersion oil used. Slides were examined at $\times 100$ using a fluorescence-equipped Olympus BX41 compound microscope. For each slide $\geq 500$ total cells were captured using an Olympus DP72 camera and cellSens Standard software (version 1.3). Images were analysed for cell abundance and volume using CellC software (Selinummi et al., 2005). Bacterial biomass was calculated using the formula given by (Romanova and Sazhin, 2010).

\section{Data analysis}

Multiple stepwise linear regression analysis was performed using SPSS Ver. 21 as an exploratory tool to understand what variables were important in influencing water quality and biological outputs. All models were validated using bootstrapping (1000 samples, 95\% confidence interval) to ensure significant regressions were not the result of chance (significance values $<0.05$ ). We created models for DOC, POC, turbidity, TN, TP, bacterial biomass and chlorophyll $a$. Independent variables used in all analysis were discharge, temperature and salinity. In addition, for testing chlorophyll a, DOC, POC, TN, TP and turbidity were used. For testing bacteria, DOC, POC, TN, TP and Chlorophyll $a$ were also employed. Data was first tested for normality via a Shapiro-Wilk test and non-normally distributed data was transformed $(\operatorname{Ln}[x+1])$, after which all variables passed $(P>0.05)$. Dependent variables were first tested against discharge as either mean daily discharge on the day of sampling $(Q 1)$ or mean 10 day antecedent discharge $(Q 10)$ to find the best fit value for discharge. $Q 10$ is the measure of the average discharge from the preceding 10 days and is used as a way to integrate the effect of previous flow events (e.g. McDowell and Asbury, 1994; Raymond and Saiers, 2010). We first tested 5, 10, 15 and 20 day antecedent discharge 
against DOC concentrations, $Q 10$ was chosen as it most commonly returned the highest $\mathrm{R}^{2}$ values. For chlorophyll a, values below the detection limit were excluded and chlorophyll $a$ was not used for analysis at stations 1 and 2 on the Clyde River due to the high number of data points below detection limits. We also performed additional multiple-regression analysis for DOC using only data recorded during base flow periods to test the hypothesis that chlorophyll $a$ would be related to DOC only during base flow periods.

Differences in DOC, POC, TN, TP, turbidity, bacterial biomass and chlorophyll $a$ between flow categories and sampling stations were analyzed using permutational multivariate analysis of variance (PERMANOVA) with PRIMER + PERMANOVA software ver. 6 (Anderson, 2001). Homogeneity of variance was tested using PERMDISP (Anderson et al., 2008). Data that was skewed was log transformed. Where unequal dispersion was still present after transformation the chances of a type-I error were reduced by rejecting the null hypotheses at a probability of 0.01. Pair-wise t-tests were employed with PERMANOVA to test which treatments and time periods were significantly different. Monte Carlo asymptotic $P$-values were generated to increase the number of permutations tested during t-tests.

\section{Results}

\section{Organic carbon concentrations}

Dissolved organic carbon (DOC) and particulate organic carbon (POC) concentrations varied greatly over time on both the Bega and Clyde Rivers (Fig. 2.2). Organic carbon concentrations were significantly different between flow categories on both rivers (Table 2.1). Concentrations were generally highest during flood flows, followed by fresh and then base flow (Fig. 2.4A,B). The exception was on the Clyde River at the lower estuary stations 4 and 5, where both DOC and POC were similar under fresh and base flow conditions. DOC was the dominant fraction of carbon present under all conditions in the estuary. 
Multiple-regression analysis showed that discharge was the most important factor of those tested in explaining organic carbon variation (Table 2.2, Fig. 2.5A,B,C,D). $Q 1$ (mean daily discharge on the day of sampling) was the most useful factor in explaining POC variance, except at station 5 on the Clyde River where $Q 10$ (mean 10 day antecedent discharge) provided a better measure. $Q 1$ was also the factor that best described variance in DOC at the upper stations on both the Bega and Clyde Rivers. At the middle and lower stations, $Q 10$ provided a better measure for explaining DOC concentrations (Table 2.2). Multipleregression analysis during only base flow periods showed discharge still explained more variation in carbon concentrations than other factors including chlorophyll $a$ (Fig. 2.5C,D).

\section{Nitrogen and Phosphorous concentrations}

Both total nitrogen (TN) and total phosphorus (TP) also varied greatly during the study period (Fig. 2.3A,B). TN was significantly different between flow categories (Table 2.1). On the Bega River TN was highest under flood flows followed by fresh and then base flow conditions (Fig. 2.4E). On the Clyde River TN was significantly higher during flood flows compared to fresh flows at stations 2 and 4, but not at stations 1, 3, 5 (Fig. 2.4F). TN was significantly higher during fresh flow compared to base flow at stations 1 and 3. Multipleregression analysis showed $Q 10$ as the best explanatory factor to explain variance in $\mathrm{TN}$ on the Clyde River (Table 2.2, Fig. 2.6D). On the Bega River variance in TN was generally better explained by $Q 1$ (Fig. 2.6C). Overall nitrogen concentrations were much lower on the Clyde River in comparison to the Bega River.

On the Bega River mean concentrations of TP were not significantly different between flood and fresh flow at the upper stations 1-3, but were significantly higher during flood flow at stations 4 and 5 (Table 2.1, Fig. 2.4G)). Multiple-regression analysis showed $Q 1$ explained the most variance in TP concentrations (Table 2.2, Fig. 2.6E). TP concentrations were very 
low on the Clyde River under all flow conditions (Fig. 2.4H). At the lower estuary stations we could find no factor from those tested that explained TP variance (Fig. 2.6F), however at the station 1 and 2 TP was positively related to $Q 1$ (Table 2.2).

\section{Turbidity and Salinity}

Mean turbidity varied greatly during the study and was significantly different between flow categories (Table 2.1). Turbidity was higher during flood flows compared to fresh flows on both rivers (Table 2.1, Fig. 2.4I, J). The exception was sampling station 5 on the Clyde River where there was no significant difference between flood and fresh flows. Turbidity was not significantly different between fresh and base flow conditions, except sampling station 1 on the Bega River where turbidity was higher during fresh flows. Turbidity was approximately 2-fold higher on the Bega River compared to the Clyde River. Multiple-regression analysis showed $Q 1$ provided the best factor in predicating variance in turbidity concentrations (Table 2.2, Fig. 2.6G,H).

Differences in salinity ranges were clear between flood, fresh and base flow conditions (Fig. $2.4 \mathrm{O}, \mathrm{P})$. On the Bega River salinity peaked at station 5 with a mean of 3 under flood flow conditions, 6 during fresh flows and 20 during base flow. On the Clyde River salinity at station 5 was 6 during flood flow, 20 under fresh flow conditions and 26 during base flow.

On the Bega River, freshwater dominated at stations 1-3 under flood and fresh flow conditions, but only extended to station 1 during base flow. On the Clyde River freshwater dominated at station 1-3 under flood conditions and station 1 during fresh flows.

\section{Bacterial Biomass}

Bacterial biomass significantly varied between flow categories (Table 2.1). During flood flows bacterial biomass was lower at the upstream station 1 on the Bega River and on the Clyde River stations 1 and 2 compared to fresh flows (Fig. 2.4M, N). At the downstream 
stations 4 and 5 the reverse was true with bacterial biomass higher during floods compared to fresh flows. Bacterial biomass was lowest during base flow conditions, except at the lower station on the Clyde River were it was similarly low during fresh flow conditions. Multipleregression showed variation in bacterial biomass at stations 1-3 on both rivers could be best explained by TP concentrations (Table 2.2, Fig. 2.7A,B). On the Bega at station 4 a combination of DOC and TP proved the best predictors of bacterial biomass and station 5 DOC was the best variable (Fig. 2.7C). On the Clyde River DOC was the best variable at station 4 and $Q 10$ the best variable at station 5 (Fig. 2.7D).

\section{Chlorophyll $a$}

Chlorophyll $a$ concentrations were significantly different between flow categories on the Bega River with the high concentrations during fresh flows at station 4 accounting for most of the difference (Table 2.1, Fig. 2.4K). On the Clyde River chlorophyll $a$ concentrations were low and often below the methodological detection limit of $<1 \mu \mathrm{g} \mathrm{L^{-1 }}$. All values below detection limits were excluded from the calculation of the means (Fig. 2.4L) and PERMANOVA analysis was not conducted on the Clyde River due to too many missing values. At most stations we were unable to create models to explain variation in chlorophyll $a$ concentrations, the exceptions were stations 4 and 5 on the Clyde River which were positively related to temperature (Table 2.2).

\section{Discussion}

\section{Discharge and organic carbon dynamics}

Discharge plays an overwhelming role in structuring organic carbon dynamics on the Bega and Clyde Rivers. We hypothesised that organic carbon would be positively related to discharge, except during base flow periods, when it would be related to chlorophyll a. Discharge was the only factor that could explain the changes in the variation of organic 
carbon concentrations for each estuary, including during base flows (Table 2.2, Fig. 2.5). This is somewhat different to many systems where autochthonous carbon and other factors such as temperature are often implicated in estuarine organic carbon dynamics (e.g. Fisher et al., 1998; Minor et al., 2006; Peterson et al., 1994). Jassby et al. (1993) found that the influence of discharge on DOC dynamics in San Francisco Bay varied both spatially within the estuary and temporally between years. The dominance of discharge may in part be explained by its highly episodic nature in South-East Australia. During this study, flood flows occurred two or three times a year and fresh flows around every month, delivering allochthonous carbon to the estuary. At the upper stations $Q 1$ was the best predictor for DOC concentrations; at downstream stations $Q 10$ was usually a better predictor. The likely main reason for this distinction in discharge variables is that retention times in the upper estuary are low; DOC concentrations there likely reflect riverine inputs on the day of sampling. At the downstream sites retention times are longer and reflect riverine DOC inputs from both the day of sampling and days prior. This study also took place during a period of above average precipitation; it is possible that over a longer period of time covering drier years that primary production may have a stronger influence over organic carbon.

Previous studies that have examined the relationship between discharge and carbon have used a dichotomy of storm and base flow to characterise different discharge conditions. Buffam et al. (2001) for example showed in freshwater streams that storm flow, whilst only occurring for a fraction of the time compared to base flow, accounted for over half the annual DOC load. Wiegner et al. (2009) and Leff and Meyer (1991) have shown that the bioavailability of DOC to heterotrophic bacteria can change between storm and base flow conditions. Our separation of storm flows into flood, fresh and base flow categories here has proven useful as a simple way of understanding how variable hydrological conditions may structure carbon dynamics. 
The highest organic carbon concentrations generally coincided with flood flows as we hypothesised (Fig. 2.4A-D). This is not surprising as it is well established that storm flows play a key role in mobilising organic carbon in catchments (Buffam et al., 2001; Hinton et al., 1997). Similar results were found in another Australian estuary, the Fitzroy River, where Ford et al. (2005) showed DOC concentrations were higher following high flows compared to base flow conditions. The role of floods in facilitating cross-boundary carbon subsidisation are emphasised in the flood pulse concept (Junk et al., 1989). The interface of terrestrialaquatic environments, particularly during flood events are recognised as important 'hot spots and moments' in biogeochemical cycling (McClain et al., 2003).

Under fresh flow conditions DOC concentrations were only moderately lower than during flood flow conditions (Fig. 2.4A-D). During fresh flows connectivity to the flood plain is likely to be minimal and from our observations did not occur in upper reaches of either river. This suggests an increased importance of organic matter from other sources such as the upper catchment, river banks and benches, in-stream production and direct riparian inputs during fresh flows. The relative contribution of POC to the total carbon pool also significantly reduced under fresh flow conditions. This is likely due to the lack of connectivity to the flood plain during fresh flows, as well as decreased erosive force compared to larger floods (Depetris and Kempe, 1993).

Our flow categories presented a different relationship between inflows and DOC on the lower stations of the Clyde River. Here DOC and POC concentrations during fresh flows were similar to base flow conditions. This is most likely due to dilution as the estuarine volume becomes significantly larger in the lower estuary and tidal exchange with the mouth increases. McKee et al. (2000) showed on the Richmond estuary, Australia, that of the total loads of TN and TP delivered to the estuary during floods, a much larger proportion was exported to the ocean during large floods compared to smaller floods. Longer retention times 
of materials also influences biological factors. For example long retention times of DOC in estuaries may lead to increased bacterial degradation (Hopkinson et al., 1998). We did not study retention times or mixing dynamics during this study however salinity data gives at least some insight into the likely differences in advective force and the penetration of freshwater downstream during fresh and flood flows (Fig. 2.4O, P).

Though the size of inflow is clearly important, the frequency and timing between flow events can also exert an influence on organic carbon concentrations. Schäfer et al. (2002) showed the period of time between flooding and inundation will affect organic matter and suspended solids export. We observed that during two similar sized floods that occurred on the Bega and Clyde Rivers during March 2012, DOC concentrations at the upper most station were 13 and $11 \mathrm{mg} \mathrm{L}^{-1}$ respectively during the first flood, and 11 and $7 \mathrm{mg} \mathrm{L}^{-1}$ respectively during a flood ten days later (Fig. 2). This pattern was also demonstrated by Buffam et al. (2001) who observed two floods in quick succession, finding DOC and nitrogen concentrations being considerably lower during the second flood. This occurrence is also regularly seen in tropical catchments where the first flush at the start of the wet season will deliver much higher loads of organic carbon before it declines, despite discharge remaining high (Brinson, 1976). This suggests that the first flow event after an extended period of base flow may be more important for delivering organic carbon to the estuary. Others have used additional hydrological variables to develop a more nuanced understanding of the influence of discharge. Examples of these include the amplitude of the rising limb of a flood, which accounts for the pre-flood river level (Puckridge et al., 1998), and discounted flow, which reflects flow history (Kuhnert et al., 2012). We did not have enough data points in our dataset to accurately employ such techniques. Integrating these into further conceptual work regarding differently sized inflow may be useful.

\section{Nutrient and turbidity dynamics}


Nitrogen and phosphorus dynamics were similar to that of carbon on the Bega River and were correlated with discharge (Fig. 2.6C-F). At the upper stations TN and TP concentrations were not significantly different between flood and fresh flow. At the lower stations TN and TP were significantly lower during fresh flows in comparison to flood flows (Fig. 2.4E-H). These results are consistent with reporting in the literature that discharge is regularly the dominant source of nitrogen and phosphorus (Bouwman et al., 2005; Boynton and Kemp, 2000; Conley et al., 1995; Froelich et al., 1982; Seitzinger et al., 2002). TN and TP and have been shown to significantly increase in concentration following flooding events (Eyre and Twigg, 1997).

Some clear distinctions between the Bega and Clyde catchments are highlighted by the TN and TP concentrations which were always 2-3 fold higher on the Bega River (Fig. 2.4). Whilst TN was positively related to discharge on the Clyde River, TP, which remained low at all times, was not or showed only a weak relationship (Fig. 2.3D). These results can be mostly explained through differences in catchment land use. The Clyde River catchment is mostly undisturbed with riparian vegetation intact (Tozer et al., 2010); TN and TP concentrations here always fell within the range expected in an unpolluted estuary (ANZECC, 2000). The Bega River has been heavily cleared for agriculture (Brierley et al., 1999; Tozer et al., 2010), in particular dairy, which is widely associated with increased nutrient loading to catchments and estuaries (Drewry et al., 2006; Harris, 2001; Jones et al., 2009).

Turbidity also showed some clear distinctions between flow categories. On both estuaries turbidity was significantly higher during flood flows compared to fresh flows. Turbidity was in turn significantly higher during fresh flows than base flows (Fig. 2.4I, J). This is an important distinction between these flow categorises as whilst mean turbidity remains low at 5-6 NTU in the Bega River during fresh flows, during flood flows it is around 18 NTU, 
enough to negatively impact on primary production by reducing light availability for autotrophs (Cloern, 1987; Lloyd et al., 1987). The turbidity results also indicate differences between catchments due to land use. Turbidity was always much higher on the Bega River, probably due to clearing of vegetation for agriculture which has led to enhanced erosion and sediment transfer to the river channel in the catchment (Fryirs and Brierley, 2001).

\section{Biological responses to discharge and changing DOC and nutrient dynamics}

Bacterial biomass and production are commonly linked to primary production or chlorophyll $a$ due to bacterial reliance on autochthonous DOC (Cole et al., 1988). However, this may not be the case in systems receiving large inputs of allochthonous DOC such as estuaries (Almeida et al., 2005; Ameryk et al., 2005). We hypothesised that bacteria would be primarily related to DOC. This hypothesis was only partly confirmed as bacteria were linked to both DOC and discharge in the lower estuary, and TP in the upper estuary (Fig. 2.7).

Bacterial biomass was never related to chlorophyll a. The likely reason for this is that the size and variation of inputs of allochthonous DOC was much greater than dissolved autochthonous carbon production. These results support findings in other studies that bacteria may be more closely related to DOC and discharge when allochthonous inputs are high (Hoch and Kirchman, 1993; Ochs et al., 2010).

Previous work conducted on these rivers has shown that bacteria are mostly carbon limited but this may switch to nitrogen or phosphorus limitation under high flow conditions when available DOC concentrations are high (Chapter 4; Hitchcock and Mitrovic, 2013). One possible explanation for a switch in factors explaining bacterial biomass variation from TP in the upper estuary to DOC and discharge in the lower estuary, may be related to the biological transformation of DOC. Bioavailability of allochthonous DOC in both estuaries to vary between 10-30\% (Chapter 3). As this DOC enters the estuary at station 1, the DOC pool may still be largely available and bacteria become phosphorus limited. As the DOC pool makes its 
way to the lower estuary it becomes more refractory and bacteria become carbon limited. Bacteria have been linked to both DOC and phosphorus in other systems (Cotner and Biddanda, 2002; Pinhassi et al., 2006). This hypothesis is supported by mean bacterial biomass at each station which, with the exception of the upstream sites during flood flows, decreased in concentration from upstream to downstream (Fig. 2.4 M,N). Another possible explanation for increases in bacteria may be due to transport from the catchment during floods. Crump et al. (2004) has previously shown that estuarine bacteria may come from a variety of sources including the terrestrial environment. Whilst some of the bacteria in the these estuaries may have originated from allochthonous sources, the variance in biomass is more likely related to in-situ growth as we previously found bacterial growth rates to be significantly higher during inflow events (Chapter 3).

In estuaries, phytoplankton are commonly linked to both temperature or season as well as available nutrients (Malone, 1977). We have previously shown that phytoplankton are primarily nitrogen limited on the Bega River and phosphorus limited on the Clyde River (Hitchcock and Mitrovic, 2013). Thus we hypothesised chlorophyll $a$ would be related to these nutrients; as well as have a broader relationship to temperature. During the study period the only factor that helped to explain chlorophyll $a$ concentrations from those tested was temperature, which is regularly found in estuaries (Eppley, 1972). However, it is relatively common for chlorophyll $a$ to be also linked to nutrient availability (Rudek et al., 1991). One possible explanation for why chlorophyll $a$ was not related to nitrogen or phosphorus may be that bacteria regularly outcompeted phytoplankton for available nutrients. It's previously been shown that bacteria can outcompete phytoplankton for nutrients due to having greater surface area to volume ratios (Currie and Kalff, 1984; Thingstad et al., 1993). We have previously seen evidence of competition for nutrients under high flow conditions on both estuaries in previous work (Hitchcock and Mitrovic, 2013). There is a range of other factors 
not measured here that may explain chlorophyll $a$ was not related to changing nitrogen and phosphorous concentrations such as grazing pressure and the presence of other nutrients such as Si and Fe (Paerl and Justic, 2013).

Bacterial biomass and chlorophyll $a$ both showed significant differences between flow categories. We hypothesised that concentrations of both would be highest under fresh flow conditions, as although flood flows may bring more resources, they may also lead to the washout of plankton from the estuary. Our results partly confirmed this hypothesis, showing that bacterial biomass was higher at the upstream stations under fresh flows compared to flood flows, though not at the middle and lower stations (Fig. 2.4M, N). The chlorophyll $a$ results showed concentrations highest during fresh flows on the Bega River, but no pattern on the Clyde River (Fig. 2.4K, L). The role of advective forcing appears to play a role during flood flows at the upper stations, likely washing bacteria and phytoplankton downstream. These results may also be related to increased residence times of organic carbon and nutrients during smaller inflows, allowing greater utilisation of materials (Battin et al., 2008). The utility of separating storm flows into flood and fresh flows appears to be useful in understanding what responses in different sections of the estuary we might expect from bacteria, but much less useful in trying to understand chlorophyll $a$ dynamics.

Freshwater inflows play a key role in many aspects of estuarine and aquatic ecosystem functioning (Roelke et al., 2012). These results support our hypothesis that discharge would be an important factor influencing carbon and nutrient dynamics on the Bega and Clyde Rivers. However, we also hypothesised that chlorophyll $a$ would be important during low flow periods; this was not the case during the study period. Chlorophyll $a$ during this study generally remained low and was most related to temperature, but not to nutrient concentrations. Bacterial biomass was related to DOC and discharge in the lower estuary which supported our hypothesis that carbon would be the main determining factor. At the 
upper stations phosphorus was the factor that best explained bacterial variation. These results have important implications for our understanding biogeochemical cycling, supporting the idea that freshwater inflow events can be considered 'hot moments' of intense transformation (McClain et al., 2003). The results also indicate that freshwater inflow events are important in facilitating a cross systems resource subsidy. Whilst there has been significant debate about the importance of allochthonous carbon in aquatic food webs (Brett et al., 2009; Hoffman et al., 2008), these results suggest that inflow events constitute key moments where significant amounts of allochthonous carbon may become available to the microbial loop and potentially available to higher trophic organisms (Fenchel, 2008).

The separation of discharge into different flow categories of flood, fresh and base flow appeared useful for understanding some factors, but less for others. Whilst carbon and nutrients were significantly lower during base flow as predicted, the differences between flood and fresh flows were mostly only seen in the lower estuary. The exception was for POC which was always much higher during flood flows in comparison to fresh flows. Similarly turbidity was also much higher during flood flows compared to fresh and base flows. Bacterial biomass and chlorophyll $a$ results also partially supported our hypothesis that concentrations would be higher under fresh flow conditions, as they were for bacteria in the upper estuary and for chlorophyll $a$ on the Bega River. Overall concentrations for all factors were generally lowest during base flow conditions. The distinction between flood and fresh flow conditions is partially limited; effecting individual factors and estuary locations differently, and is likely influenced by a range of interrelated factors beyond the scope of this study. The significant differences that were witnessed between flood and fresh flows however suggest that future research into understanding the influence of differently sized inflows will be important in estuarine systems. This will be particularly important as many coastal 
catchments have had their flow regimes radically altered through extraction and the presence of dams.

\section{Acknowledgements}

This work was supported by the Peter Cullen Postgraduate Scholarship funded by the NSW

Office of Water, Sydney Catchment Authority, State Water, Hunter Water and Sydney Water.

Dr John Brayan and the staff of the NSW Office of Water laboratory are thanked for their

assistance in sample analysis. The following people are thanked for their assistance with field and lab assistance: Ann-Marie Rohlfs, Hannah Walters, Carla Thomas, Jordan Ilses, David Ryan, Tessa Rex, Rebecca Pearse, Patch Sinclair, Dayna Williams, Alice Blackwood, Chris Moore, Emma Kefford, Jessica Minshall and Charles Charleston.

\section{References}

Abrantes, K.G., Sheaves, M., 2010. Importance of freshwater flow in terrestrial-aquatic energetic connectivity in intermittently connected estuaries of tropical Australia. Marine Biology 157, 20712086.

Almeida, M.A., Cunha, M.A., Alcantara, F., 2005. Relationship of bacterioplankton production with primary production and respiration in a shallow estuarine system (Ria de Aveiro, NW Portugal). Microbiological Research 160, 315-328.

Ameryk, A., Podgorska, B., Witek, Z., 2005. The dependence between bacterial production and environmental conditions in the Gulf of Gdansk. Oceanologia 47, 27-45.

Anderson, M., Gorley, R., Clarke, K., 2008. PERMANOVA+ for PRIMER: guide to software and statistical methods. Primer-e, Plymouth, UK.

Anderson, M.J., 2001. A new method for non-parametric multivariate analysis of variance. Austral Ecology 26, 32-46.

ANZECC, 2000. Australian and New Zealand guidelines for fresh and marine water quality. Australian and New Zealand Environment and Conservation Council and Agriculture and Resource Management Council of Australia and New Zealand, Canberra.

APHA, 2005. Standard methods for the examination of water and wastewater, 21 ed. American Public Health Association, Washington, D.C.

Battin, T., Kaplan, L., Findlay, S., Hopkinson, C., Marti, E., Packman, A., Newbold, J., Sabater, F., 2008. Biophysical controls on organic carbon fluxes in fluvial networks. Nature Geoscience 1, 95-100. Bouwman, A., Van Drecht, G., Knoop, J., Beusen, A., Meinardi, C., 2005. Exploring changes in river nitrogen export to the world's oceans. Global Biogeochemical Cycles 19.

Boynton, W.R., Kemp, W.M., 2000. Influence of river flow and nutrient loads on selected ecosystem processes. Estuarine Science, a Synthetic Approach to Research and Practice, JE Hobbie (Ed.). Island Press, Washington, DC, 269-298. 
Brett, M.T., Kainz, M.J., Taipale, S.J., Seshan, H., 2009. Phytoplankton, not allochthonous carbon, sustains herbivorous zooplankton production. Proc. Natl. Acad. Sci. U. S. A. 106, 21197-21201. Brierley, G.J., Cohen, T., Fryirs, K., Brooks, A., 1999. Post-European changes to the fluvial geomorphology of Bega catchment, Australia: implications for river ecology. Freshwater Biology 41, 839-848.

Brinson, M.M., 1976. Organic matter losses from four watersheds in the humid tropics. Limnology and oceanography 21, 572-582.

Brooks, A.P., Brierley, G.J., 1997. Geomorphic responses of lower Bega River to catchment disturbance, 1851-1926. Geomorphology 18, 291-304.

Buffam, I., Galloway, J., Blum, L., McGlathery, K., 2001. A stormflow/baseflow comparison of dissolved organic matter concentrations and bioavailability in an Appalachian stream.

Biogeochemistry 53, 269-306.

Cauwet, G., 2002. DOM in the coastal zone, in: Hansell, D.A., Carlson, C.A. (Eds.), Biogeochemistry of Marine Dissolved Organic Matter. Academic Press, Amsterdam, pp. 579-609.

Cloern, J., 1987. Turbidity as a control on phytoplankton biomass and productivity in estuaries. Continental Shelf Research 7, 1367-1381.

Cole, J., Findlay, S., Pace, M., 1988. Bacterial production in fresh and saltwater ecosystems: a crosssystem overview. Marine Ecology Progress Series 43, 1-10.

Cole, J., Prairie, Y., Caraco, N., McDowell, W., Tranvik, L., Striegl, R., Duarte, C., Kortelainen, P., Downing, J., Middelburg, J., 2007. Plumbing the global carbon cycle: integrating inland waters into the terrestrial carbon budget. Ecosystems 10, 172-185.

Conley, D.J., Smith, W.M., Cornwell, J.C., Fisher, T.R., 1995. Transformation of particle-bound phosphorus at the land-sea interface. Estuarine, Coastal and Shelf Science 40, 161-176.

Cotner, J.B., Biddanda, B.A., 2002. Small players, large role: Microbial influence on biogeochemical processes in pelagic aquatic ecosystems. Ecosystems 5, 105-121.

Crump, B.C., Hopkinson, C.S., Sogin, M.L., Hobbie, J.E., 2004. Microbial biogeography along an estuarine salinity gradient: combined influences of bacterial growth and residence time. Applied and Environmental Microbiology 70, 1494-1505.

Currie, D.J., Kalff, J., 1984. A comparison of the abilities of freshwater algae and bacteria to acquire and retain phosphorus. Limnology and Oceanography 29, 298-310.

Day, J.W., Kemp, W.M., Crump, B.C., Yáñez-Arancibia, A., 2012. Estuarine Ecology. Wiley.

Depetris, P.J., Kempe, S., 1993. Carbon dynamics and sources in the Paraná River. Limnology and Oceanography 38, 382-395.

Drewry, J.J., Newham, L.T.H., Greene, R.S.B., Jakeman, A.J., Croke, B.F.W., 2006. A review of nitrogen and phosphorus export to waterways: context for catchment modelling. Marine and Freshwater Research 57, 757-774.

Eppley, R.W., 1972. Temperature and phytoplankton growth in the sea. Fishery Bulletin 70, 10631085.

Eyre, B., Twigg, C., 1997. Nutrient Behaviour During Post-flood Recovery of the Richmond River Estuary, Northern NSW, Australia. Estuarine, Coastal and Shelf Science 44, 311-326.

Fenchel, T., 2008. The microbial loop-25 years later. Journal of Experimental Marine Biology and Ecology 366, 99-103.

Findlay, S., 2003. Bacterial response to variation in dissolved organic matter, Aquatic ecosystems: interactivity of dissolved organic matter, pp. 363-379.

Findlay, S., Pace, M., Lints, D., Howe, K., 1992. Bacterial metabolism of organic carbon in the tidal freshwater Hudson Estuary. Marine Ecology Progress Series 89, 147-153.

Findlay, S., Sinsabaugh, R.L., 2003. Aquatic ecosystems: Interactivity of dissolved organic matter. Academic Press, San Diego.

Finlayson, B., McMahon, T., 1988. Australia vs the world: a comparative analysis of streamflow characteristics, in: Warner, R.F. (Ed.), Fluvial geomorphology of Australia. Academic Press: Sydney., Sydney, pp. 17-40. 
Fisher, T.R., Hagy, J.D., Rochelle-Newall, E., 1998. Dissolved and particulate organic carbon in Chesapeake Bay. Estuaries 21, 215-229.

Ford, P., Tillman, P., Robson, B., Webster, I., 2005. Organic carbon deliveries and their flow related dynamics in the Fitzroy estuary. Marine Pollution Bulletin 51, 119-127.

Fouilland, E., Mostajir, B., 2010. Revisited phytoplanktonic carbon dependency of heterotrophic bacteria in freshwaters, transitional, coastal and oceanic waters. FEMS microbiology ecology 73, 419-429.

Froelich, P., Bender, M., Luedtke, N., Heath, G., DeVries, T., 1982. The marine phosphorus cycle. American Journal of Science 282, 474-511.

Fryirs, K., Brierley, G.J., 2001. Variability in sediment delivery and storage along river courses in Bega catchment, NSW, Australia: implications for geomorphic river recovery. Geomorphology 38, 237265.

Harris, G.P., 2001. Biogeochemistry of nitrogen and phosphorus in Australian catchments, rivers and estuaries: effects of land use and flow regulation and comparisons with global patterns. Marine and Freshwater Research 52, 139-149.

Hinton, M., Schiff, S., English, M., 1997. The significance of storms for the concentration and export of dissolved organic carbon from two Precambrian Shield catchments. Biogeochemistry 36, 67-88. Hitchcock, J.N., Mitrovic, S.M., 2013. Different resource limitation by carbon, nitrogen and phosphorus between base flow and high flow conditions for estuarine bacteria and phytoplankton. Estuarine, Coastal and Shelf Science 135, 106-115.

Hoch, M., Kirchman, D., 1993. Seasonal and inter-annual variability in bacterial production and biomass in a temperate estuary. Marine Ecology Progress Series 98, 283-295.

Hoffman, J.C., Bronk, D.A., Olney, J.E., 2008. Organic matter sources supporting lower food web production in the tidal freshwater portion of the York River estuary, Virginia. Estuaries and Coasts 31, 898-911.

Hopkinson, C.S., Buffam, I., Hobbie, J., Vallino, J., Perdue, M., Eversmeyer, B., Prahl, F., Covert, J., Hodson, R., Moran, M.A., 1998. Terrestrial inputs of organic matter to coastal ecosystems: An intercomparison of chemical characteristics and bioavailability. Biogeochemistry 43, 211-234. Jassby, A., Cloern, J., Powell, T., 1993. Organic carbon sources and sinks in San Francisco Bay: Variability induced by river flow. Marine Ecology Progress Series 95, 39-54.

Jones, M.G., Vervoort, R.W., Cattle, J., 2009. Nutrient losses under simulated rainfall from pasture plots in the Great Lakes District, New South Wales. Australian Journal of Soil Research 47, 555-564. Junk, W., Bayley, P., Sparks, R., 1989. The flood pulse concept in river-floodplain systems. Canadian Special Publication of Fisheries and Aquatic Sciences 106, 110-127.

Kuhnert, P.M., Henderson, B.L., Lewis, S.E., Bainbridge, Z.T., Wilkinson, S.N., Brodie, J.E., 2012. Quantifying total suspended sediment export from the Burdekin River catchment using the loads regression estimator tool. Water Resources Research 48, 1-18.

Leff, L.G., Meyer, J.L., 1991. Biological availability of dissolved organic carbon along the Ogeechee River. Limnology and Oceanography 36, 315-323.

Lim, K.J., Engel, B.A., Tang, Z., Choi, J., Kim, K.S., Muthukrishnan, S., Tripathy, D., 2005. Automated Web Gis based hydrograph analysis tool, WHAT1. Journal of the American Water Resources Association 41, 1407-1416.

Lin, J.-Y., Cheng, C.-T., Chau, K.-W., 2006. Using support vector machines for long-term discharge prediction. Hydrological Sciences Journal 51, 599-612.

Lloyd, D.S., Koenings, J.P., Laperriere, J.D., 1987. Effects of turbidity in fresh waters of Alaska. North American Journal of Fisheries Management 7, 18-33.

Malone, T.C., 1977. Environmental regulation of phytoplankton productivity in the lower Hudson estuary. Estuarine and Coastal Marine Science 5, 157-171.

McClain, M.E., Boyer, E.W., Dent, C.L., Gergel, S.E., Grimm, N.B., Groffman, P.M., Hart, S.C., Harvey, J.W., Johnston, C.A., Mayorga, E., 2003. Biogeochemical hot spots and hot moments at the interface of terrestrial and aquatic ecosystems. Ecosystems 6, 301-312. 
McDowell, W.H., Asbury, C.E., 1994. Export of carbon, nitrogen, and major ions from three tropical montane watersheds. Limnology and Oceanography 39, 111-125.

McKee, L.J., Eyre, B.D., Hossain, S., 2000. Transport and retention of nitrogen and phosphorus in the sub-tropical Richmond River estuary, Australia-A budget approach. Biogeochemistry 50, 241-278. Minor, E.C., Simjouw, J.P., Mulholland, M.R., 2006. Seasonal variations in dissolved organic carbon concentrations and characteristics in a shallow coastal bay. Marine Chemistry 101, 166-179. Ning, X.R., Li, W.K.W., Cai, Y.M., Shi, J.X., 2005. Comparative analysis of bacterioplankton and phytoplankton in three ecological provinces of the northern South China Sea. Marine Ecology Progress Series 293, 17-28.

Ochs, C.A., Capello, H.E., Pongruktham, O., 2010. Bacterial production in the Lower Mississippi River: importance of suspended sediment and phytoplankton biomass. Hydrobiologia 637, 19-31. Paerl, H.W., Justic, D., 2013. Estuarine phytoplankton, in: Day Jr, J.W., Yanez-Arancibia, A., Kemp, W.M., Crump, B.C. (Eds.), Estuarine ecology, 2 ed. Wiley, Hoboken, pp. 85-110.

Peterson, B., Fry, B., Hullar, M., Saupe, S., Wright, R., 1994. The distribution and stable carbon isotopic composition of dissolved organic carbon in estuaries. Estuaries and Coasts 17, 111-121. Petrone, K.C., 2010. Catchment export of carbon, nitrogen, and phosphorus across an agro-urban land use gradient, Swan-Canning River system, southwestern Australia. Journal of Geophysical Research: Biogeosciences 115, 1-16.

Petrone, K.C., Fellman, J.B., Hood, E., Donn, M.J., Grierson, P.F., 2011. The origin and function of dissolved organic matter in agro-urban coastal streams. Journal of Geophysical Research:

Biogeosciences 116, 1-13.

Petrone, K.C., Richards, J.S., Grierson, P.F., 2009. Bioavailability and composition of dissolved organic carbon and nitrogen in a near coastal catchment of south-western Australia. Biogeochemistry 92, 27-40.

Pinhassi, J., Gomez-Consarnau, L., Alonso-Saez, L., Sala, M.M., Vidal, M., Pedros-Alio, C., Gasol, J.M., 2006. Seasonal changes in bacterioplankton nutrient limitation and their effects on bacterial community composition in the NW Mediterranean Sea. Aquatic Microbial Ecology 44, 241-252. Porter, K., Feig, Y., 1980. The use of DAPI for identifying and counting aquatic microflora. Limnology and Oceanography 25, 943-948.

Puckridge, J., Sheldon, F., Walker, K.F., Boulton, A., 1998. Flow variability and the ecology of large rivers. Marine and Freshwater Research 49, 55-72.

Raymond, P.A., Saiers, J.E., 2010. Event controlled DOC export from forested watersheds. Biogeochemistry 100, 197-209.

Roelke, D.L., Spatharis, S., Mitrovic, S.M., 2012. A new hydrology: effects on ecosystem form and functioning. Canadian Journal of Fisheries and Aquatic Sciences 69, 1377-1379.

Romanova, N., Sazhin, A., 2010. Relationships between the cell volume and the carbon content of bacteria. Oceanology 50, 522-530.

Roy, P.S., Williams, R.J., Jones, A.R., Yassini, I., Gibbs, P.J., Coates, B., West, R.J., Scanes, P.R., Hudson, J.P., Nichol, S., 2001. Structure and Function of South-east Australian Estuaries. Estuarine, Coastal and Shelf Science 53, 351-384.

Rudek, J., Paerl, H.W., Mallin, M.A., Bates, P.W., 1991. Seasonal and hydrological control of phytoplankton nutrient limitation in the lower Neuse River Estuary, North Carolina. Marine Ecology Progress Series 75, 133-142.

Schäfer, J., Blanc, G., Lapaquellerie, Y., Maillet, N., Maneux, E., Etcheber, H., 2002. Ten-year observation of the Gironde tributary fluvial system: fluxes of suspended matter, particulate organic carbon and cadmium. Marine Chemistry 79, 229-242.

Seitzinger, S., Kroeze, C., Bouwman, A., Caraco, N., Dentener, F., Styles, R., 2002. Global patterns of dissolved inorganic and particulate nitrogen inputs to coastal systems: Recent conditions and future projections. Estuaries 25, 640-655.

Selinummi, J., Seppala, J., Yli-Harja, O., Puhakka, J.A., 2005. Software for quantification of labeled bacteria from digital microscope images by automated image analysis. BioTechniques 39, 859 . 
Tank, J.L., Rosi-Marshall, E.J., Griffiths, N.A., Entrekin, S.A., Stephen, M.L., 2010. A review of allochthonous organic matter dynamics and metabolism in streams. Journal of the North American Benthological Society 29, 118-146.

Thingstad, T.F., Skjoldal, E.F., Bohne, R.A., 1993. Phosphorus cycling and algal-bacterial competition in Sandsfjord, western Norway. Marine Ecology Progress Series 99, 239-239.

Thingstad, T.F., Zweifel, U.L., Rassoulzadegan, F., 1998. P limitation of heterotrophic bacteria and phytoplankton in the northwest Mediterranean. Limnology and Oceanography, 88-94.

Thottathil, S.D., Balachandran, K.K., Gupta, G.V.M., Madhu, N.V., Nair, S., 2008. Influence of allochthonous input on autotrophic-heterotrophic switch-over in shallow waters of a tropical estuary (Cochin Estuary), India. Estuarine Coastal and Shelf Science 78, 551-562.

Tozer, M., Turner, K., Simpson, C., Keith, D., Beukers, P., MacKenzie, B., Tindall, D., Pennay, C., 2010. Native vegetation of southeast NSW: a revised classification and map for the coast and eastern tablelands. Royal Botanic Gardens, Sydney, National Herbarium of New South Wales.

Vargas, C.A., Martinez, R.A., San Martin, V., Aguayo, M., Silva, N., Torres, R., 2011. Allochthonous subsidies of organic matter across a lake-river-fjord landscape in the Chilean Patagonia:

Implications for marine zooplankton in inner fjord areas. Continental Shelf Research 31, 187-201.

Webster, J., Benfield, E., Golladay, S., Hill, B., Hornick, L., Kazmierczak, R., Perry, W., 1987.

Experimental studies of physical factors affecting seston transport in streams. Limnology and Oceanography 32, 848-863.

Westhorpe, D.P., Mitrovic, S.M., 2012. Dissolved organic carbon mobilisation in relation to variable discharges and environmental flows in a highly regulated lowland river. Marine and Freshwater Research 63, 1218-1230.

Wiegner, T.N., Tubal, R.L., MacKenzie, R.A., 2009. Bioavailability and export of dissolved organic matter from a tropical river during base-and stormflow conditions. Limnology and Oceanography 54, $1233-1242$.

\section{List of figures}

Figure 1. Map of the Bega and Clyde River catchments, NSW, Australia. Numbers indicate sampling stations.

Figure 2. Time series of discharge and organic carbon values at sampling station 1 on the A)

Bega and B) Clyde Rivers. Circles indicate dissolved organic carbon and triangles particulate organic carbon.

Figure 3. Time series of discharge and nutrients at sampling station 1. A) TN on the Bega

River, B) TP on the Bega River, C) TN on the Clyde River, D) TP on the Clyde River.

Figure 4. Mean concentrations of various constituents under flood, fresh an base flow

categories. A) DOC, Bega River, B) POC, Bega River, C) TN, Bega River, D) TP, Bega

River, E) turbidity, Bega River, F) chlorophyll $a$, Bega River, G) DOC, Clyde River, H) 
POC, Clyde River, I) TN Clyde River, J) TP, Clyde River, K) turbditiy, Clyde River, L) chlorophyll $a$, Clyde River. Error bars are standard error.

Figure 5. Results of the multiple stepwise linear regression analysis for DOC on the Bega and Clyde Rivers at sampling station 5. A) Ln DOC vs Ln 10 day antecedent discharge on the Bega River, B) Ln DOC vs Ln 10 day antecedent discharge on the Bega River, C) Ln DOC vs Ln Chlorophyll $a$ on the Bega River, D) Ln DOC vs Ln Chlorophyll $a$ on the Clyde River. Closed circles are samples taken during flood and flow conditions, open circles are samples taken during base flow conditions.

Figure 6. Results of the multiple stepwise linear regression analysis for POC, TN, TP and turbidity on the Bega and Clyde Rivers at sampling station 5. A) Ln POC vs Ln discharge, Bega River, B) ) Ln POC vs Ln 10 day antecedent discharge, Clyde River, C) Ln TN vs Ln discharge Bega River, D) Ln TN vs Ln 10 day antecedent discharge, Clyde River, E) Ln TP vs Ln discharge,Bega River, F) Ln TP vs Ln 10 day antecedent discharge, Clyde River, G) Ln turbidity vs Ln discharge, Bega River, H) Ln turbidity vs Ln 10 day antecedent discharge, Clyde River.

Figure 7. Results of the multiple stepwise linear regression analysis for bacterial biomss on the Bega and Clyde Rivers. A) Ln bacterial biomss vs Ln TP, Bega River, station 1, B) Ln bacterial biomass vs Ln TP Clyde River, station 1, C) Ln bacterial biomass vs Ln DOC, Bega River, station 5, D) Ln bacterial biomass vs Ln 10 day antecedent discharge, Clyde River, station 5. 
